\title{
Structure of macroinvertebrate communities in riffles of a Neotropical karst stream in the wet and dry seasons
}

\author{
Estrutura das comunidades de macroinvertebrados em corredeiras \\ de um riacho cárstico Neotropical nas estaçôes seca e chuvosa
}

\author{
Karina Ocampo Righi-Cavallaro ${ }^{1}$, Kennedy Francis Roche ${ }^{2}$, \\ Otávio Froehlich ${ }^{2}$ and Marcel Rodrigo Cavallaro ${ }^{1}$
}
${ }^{1}$ Departamento de Biologia, Faculdade de Filosofia, Ciências e Letras, Universidade de São Paulo - USP,
Av. Bandeirantes, 3900, CEP 14040-901, Ribeirão Preto, SP, Brazil e-mail: karina.righi@gmail.com,mrcallaro@gmail.com
${ }^{2}$ Universidade Federal de Mato Grosso do Sul - UFMS, Cidade Universitária, s/n, CP 549, CEP 79070-900, Campo Grande, MS, Brazil e-mail: kroche@nin.ufms.br, otavio.froehlich@ufms.br

\begin{abstract}
Aim: Our study evaluated the effects of physical and chemical variables and seasonality on diversity and structure of the macroinvertebrate fauna in riffles of a Neotropical chalk stream; Methods: Sampling was performed during the dry (September 2003) and rainy (March 2004) seasons, in five sites. Five samples were taken at each point with a Surber sampler. Physical and chemical variables were also evaluated; Results: Temperature, $\mathrm{pH}$, orthophosphate and total nitrogen were very similar for both seasons, while riffle length, conductivity, alkalinity, ammonia, phosphorus and leaf litter had different values. The total number of organisms collected was 25114 belonging to at least 50 families. Insects dominated in the samples. The highest abundance was found for the dry period. Temporary stretches were sampled in rainy season in order to complement the faunal inventory; Conclusions: The environmental seasonality was an important factor for structuring the macroinvertebrate fauna, with a significant difference between the invertebrate compositions in the sampling periods. The results of this study demonstrate the influences of seasonality on the temporal variation of communities.
\end{abstract}

Keywords: aquatic macroinvertebrates, seasonality, Neotropical chalk stream, riffle, intermittent habitat.

Resumo: Objetivos: Este estudo avaliou os efeitos das variáveis químicas e físicas e da sazonalidade na diversidade e estrutura da fauna de macroinvertebrados em corredeiras de um riacho cárstico Neotropical; Métodos: As coletas foram realizadas durante as estaçóes seca (Setembro 2003) e chuvosa (Março 2004), em cinco pontos de amostragem. Em cada ponto foram coletadas cinco unidades amostrais utilizando um amostrador Surber. Variáveis químicas e físicas também foram avaliadas; Resultados: Temperatura, $\mathrm{pH}$, ortofosfato e nitrogênio total foram muito similares entre as estaçóes, enquanto os valores de comprimento da corredeira, condutividade, alcalinidade, amônia, fósforo total e a quantidade de folhiço variaram. O número total de organismos coletado foi 25114 pertencentes, a pelo menos, 50 famílias. Insetos constituíram o grupo dominante nas amostras. Trechos temporários foram amostrados na estaçáo chuvosa, com o intuito de complementar o inventário faunístico; Conclusóes: A sazonalidade ambiental foi um fator importante na estruturação da fauna de macroinvertebrados, onde uma diferença significativa entre a composição dos macroinvertebrados aquáticos nos períodos amostrados foi observada. Os resultados deste estudo demonstram a influência da sazonalidade na variação temporal da comunidade.

Palavras-chave: macroinvertebrados aquáticos, sazonalidade, riacho cárstico Neotropical, corredeira, habitat intermitente. 


\section{Introduction}

Aquatic macroinvertebrates are important components in the ecological dynamics of lotic environments. These organisms play significant roles in energy fluxes and nutrient cycling (Wallace and Webster, 1996). They are also widely used in biomonitoring (Sandin and Hering, 2004).

According to Church (1996), variations in catchment geology, channel morphology, discharge and sediment transport determine streambed structure and create distinct morphological units such as riffles and pools within streams. Riffles are normally perceived as homogeneous morphological units, consisting of coarse substrata. In streams, macroinvertebrate distribution is regulated by interaction among substrate type (Buss et al., 2004), allochthonous matter (Cummins and Klug, 1979), water temperature (Merritt and Cummins, 1996), hydraulic conditions (Statzner et al., 1988), disturbance (Siegfried and Knight, 1977) and biotic interactions (Kohler, 1992).

In Brazil, much of the research on benthic macroinvertebrates has been taxonomic in nature (Froehlich, 2007). Although, in recent years, the number of ecological works on macroinvertebrates communities in lotic environments has increased (e.g. Baptista et al., 2000; Melo and Froehlich, 2001; Kikuchi and Uieda, 2005), there are still many ecoregions and ecosystem types poorly studied such as the centre-west (Favero and Conte, 2003; Tanaka et al., 2006).

Hydrological variability within aquatic ecosystems is one of the primary factors controlling the distribution of lotic fauna (Townsend et al., 1987; Wood et al., 2001; Smith et al., 2003). This hydrological variability can be an important factor leading to decreases in macroinvertebrate abundances in both tropical and temperate streams (Dudgeon, 1999; Death, 2008). Thus, various studies have found decreased abundances in macroinvertebrate communities in the wet season, and this has generally been attributed to the scouring effects of increased flow (Flecker and Feifarek, 1994; Bispo et al., 2001). Karst streams and rivers are particularly prone to hydraulic extremes of drought and floods (Jennings, 1985; Meyer et al., 2003; Smith et al., 2003; Stubbington et al., 2009). These landscapes are characterized by efficient flow of groundwater through conduits that become larger as the bedrock dissolves. In karst areas, water commonly drains rapidly into the subsurface at zones of recharge and then through a network of fractures, partings, and caves, and emerges at the surface in zones of discharge at springs, seeps, and wells (Ford and Williams, 2007). Karstic landscapes usually include temporary lotic ecosystems (Meyer et al., 2003).

Water $\mathrm{pH}$ is considered to be an important factor influencing the community composition of macroinvertebrates (Wright, 1995). Karst systems have characteristically high levels of water hardness, alkalinity and $\mathrm{pH}$ (Jennings, 1985); the degree to which this is reflected in the nature of their macroinvertebrate communities requires investigation.

The aim of this study was to carry out an inventory of the macroinvertebrate fauna and evaluate the effects of physical and chemical parameters and seasonality (dry and rainy seasons) on community structure, at five riffle sites in a karst stream, located in the center-west of Brazil.

\section{Material and Methods}

\subsection{Study area}

The study area was a section of the Salobrinha Stream, municipality of Bodoquena in Mato Grosso do Sul State, Brazil (56 45' 50.3” W and $\left.20^{\circ} 40^{\prime} 00.3^{\prime \prime} \mathrm{S}\right)$. The stream originates at an altitude of circa $600 \mathrm{~m}$, near the western border of the Bodoquena plateau, is $22 \mathrm{~km}$ long, and runs mainly through a narrow and deep valley. At an altitude of $170 \mathrm{~m}$ it joins the Salobra River, which in turn is a tributary of the Miranda River, in the Paraguay River Basin. According to Boggiani (1999), the plateau is sustained by Precambrian carbonate rocks, and shows characteristics of initial phases of karstic development such as areas of water penetration and sub-surface outflow. Due to the karstic nature of the region, the stream has intermittent surface flow in at least half its length. The water is very clear, becoming turbid after heavy rains. Flash floods occur several times during the rainy season. In this period the stream width increases, making available habitats to be colonized, called here "temporary stretches". The climate is tropical, characterized by the presence of two marked seasons: a rainy period, from October to March, and a dry one from April to September. The regional vegetation is Semi-deciduous Forest with species typical of riparian habitats occurring in the narrow valley floor (Damasceno Jr. et al., 2000). Five sampling sites were chosen along $7 \mathrm{~km}$ of Salobrinha stream. In this section, the stream order varied from $3^{\text {rd }}$ to $4^{\text {th }}$, without large flow variation (Figure 1). This stretch 


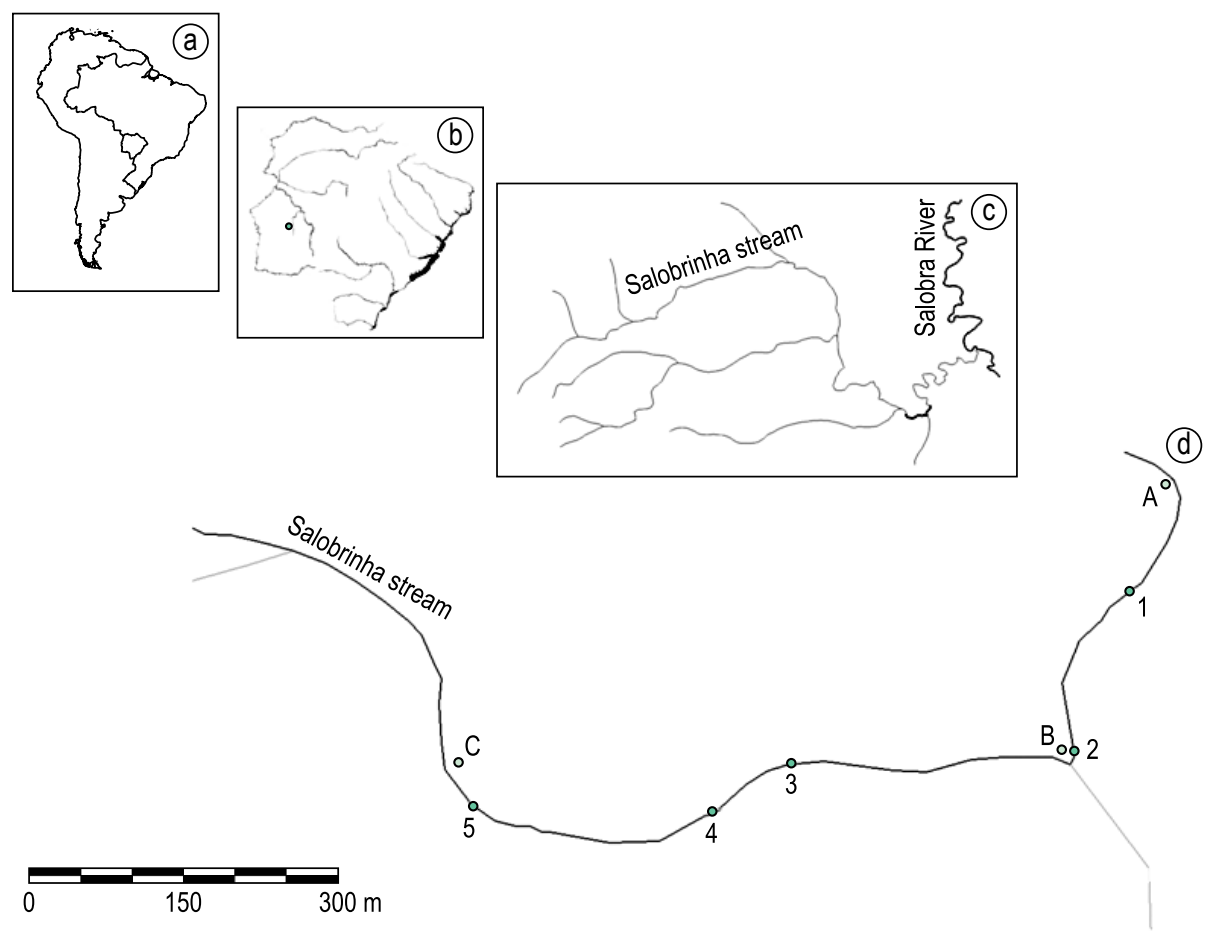

Figure 1. Map showing the localization of study area: a) within of South America, outlines of Brazil and Mato Grosso do Sul State; b) precise localization of Salobrinha Stream on Paraguay River Basin; c) bold line indicating the studied stretch; and d) distribution of sampled points inside studied stretch: 1-5) riffles sampled twice and A-C temporary riffles sampled along rainy period.

was chosen for being perennial, easily accessed and by presenting preserved riparian vegetation.

\subsection{Collection and identification}

Sampling was carried out during dry (September 2003) and rainy (March 2004) periods. At each sample site, water depth, riffle width, riffle length, $\mathrm{pH}$, water temperature, dissolved oxygen, and conductivity were recorded. In addition, a sample of water was taken for laboratory analysis of each of the following physical and chemical variables: alkalinity, phosphorus, ammonia, total nitrogen, soluble reactive phosphorus, turbidity, total suspended solids and volatile suspended solids. The macroinvertebrates were collected with a Surber sampler (area of $0.1224 \mathrm{~m}^{2}$ and $0.250 \mathrm{~mm}$ mesh); at each point five sampling units were collected along the riffles. In order to complement the inventory effort, additional three sampling units were collected at temporary stretches in the rainy period. All samples were fixed with $10 \%$ formalin. In the laboratory, the material was sorted using a stereomicroscope, and the organisms preserved in $80 \%$ ethanol. The leaf litter contained in each sample was sorted, dehydrated at $60{ }^{\circ} \mathrm{C}$ during 96 hours and then weighed. Invertebrates were identified to family level when possible. The following identification keys were used: Costa et al. (2006); Fernández and Domínguez (2001); Froehlich (1984); Merritt and Cummins (1996) and Nieser and Melo (1997).

\subsection{Data analysis}

Data from temporary stretches were analyzed separately, and not included in the following analysis. These data are presented for inventory purposes (qualitative data). Seasonal differences in the values of the physical and chemical variables were examined using one-way ANOVA. Indicator taxon analysis was performed following the method described by Dufrêne and Legendre (1997) using the software PC-ORD 4.1 McCune and Mefford (1999).

NMDS was used to assess temporal differences in species assemblages onto two-dimensional plot and was based on a Bray-Curtis similarity matrix. The NMDS stress was calculated to indicate the representativeness of this analysis. Stress values below 0.2 represent a good adjustment of the ordination (Clarke and Warwick, 2001). One-way ANOSIM was used to test for differences in the macroinvertebrate fauna composition between 
sampled periods using the software Primer v5 Clarke and Gorley, 2001. $\log (x+1)$ transformed abundances were used to calculate a similarity matrix used in NMDS and ANOSIM. The $\log (x+1)$ transformed abundance matrix and standardized environmental matrix were submitted to Canonical Correspondence Analysis (CCA) to estimate the relationships between the physical and chemical variables, the sampling sites and the invertebrate groups using the software MVSP v3.13 Kovach Computing Service (2006). Explanatory variables were assessed for multicollinearity before the analysis. High correlation (> 0.7) was verified between water temperature, riffle width, alkalinity, Ammonia, SRP, total suspended solids, leaf litter with conductivity. Therefore, conductivity, riffle length, Phosphorus, total Nitrogen and volatile suspended solids were included in the CCA.

\section{Results}

The studied stretch was characterized by rocky substrate, clear water, high conductivity, high $\mathrm{pH}$, high alkalinity, low turbidity and high dissolved oxygen concentrations (Table 1). Higher ammonia and total nitrogen concentrations were found in the dry period, as well as greater quantities of accumulated leaf litter. On the other hand, phosphorus concentrations were lower in this period. Phosphorus concentrations and total suspended solids did not vary significantly between the sampled periods. ANOVA indicated that values of riffle length, conductivity, alkalinity, ammonia, phosphorus, volatile suspended solids and leaf litter varied as a function of the sampling period (Table 1).

A total of 25114 macroinvertebrates were collected, belonging to at least 50 families (Table 2). Aquatic insects were the dominant group, with 43 families distributed in 12 orders. The dry period presented the highest abundance with 23043 individuals (7530 individuals per $\mathrm{m}^{2}$ ) being collected, belonging to 48 taxa. The family Chironomidae presented the greatest abundance, followed by Elmidae and Leptophlebiidae. Oligochaeta, Curculionidae, Culicidae, Gerridae, Mesoveliidae, Veliidae, Pyralidae and Odontoceridae were found only in this period (Table 2). In the rainy period 2071 individuals (677 individuals per $\mathrm{m}^{2}$ ) were collected, belonging to 42 taxa. Only two taxa were found exclusively in this period, namely Tabanidae and Leptoceridae. The more abundant taxa were the same as for the dry period, but the family Elmidae presented the greatest abundance, followed by Leptophlebiidae and Chironomidae (Table 2).

A total of 402 specimens (209 individuals per $\mathrm{m}^{2}$ ) were collected in the temporary stretches, representing 25 of the 50 taxa recorded herein (Table 2). No taxon was exclusive of the temporary stretches. The families Elmidae, Leptophlebiidae, Helicopsyche and Chironomidae were most common in these habitats.

Oligochaeta, Hydracarina, Elmidae Isotomyidae, Ceratopogonidae, Chironomidae, Empididae, Simuliidae, Tipulidae, Leptohyphidae, Leptophlebiidae, Gerridae, Perlidae, Hydropsychidae and Hydroptilidae were the 15 taxa that indicated the dry period. No taxon was an indicator of the rainy period (Table 2 ).

The Non-metric Multidimensional Scaling analysis showed a clear separation of the invertebrate community compositions in the two distinct periods. The one-way ANOSIM test showed that the macroinvertebrate fauna composition differed significantly among the sampled periods $(\mathrm{R}=0.716 ; \mathrm{p}<0.01)$ (Figure 2).

The first three axes of the CCA explained $62 \%$ of the variation in the data set (Table 3). The invertebrate communities in the rainy period were most correlated with riffle length. In the dry period, these communities were correlated with total nitrogen and conductivity (Figure 3).

\section{Discussion}

The results of the present study indicate the influences of seasonality on the communities, specifically, low abundance in the rainy season.

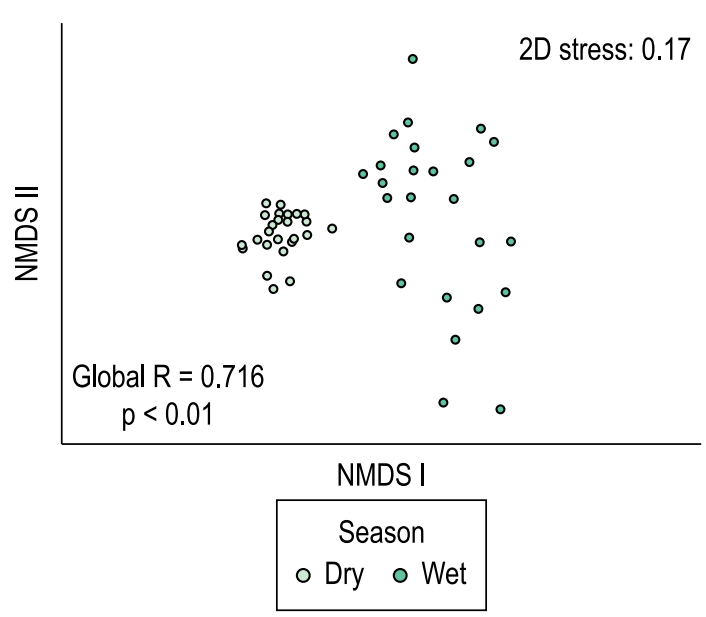

Figure 2. Two-dimensional non-metric multidimensional scaling (NMDS) of sample periods in the Salobrinha stream, Bodoquena, Mato Grosso do Sul State. 


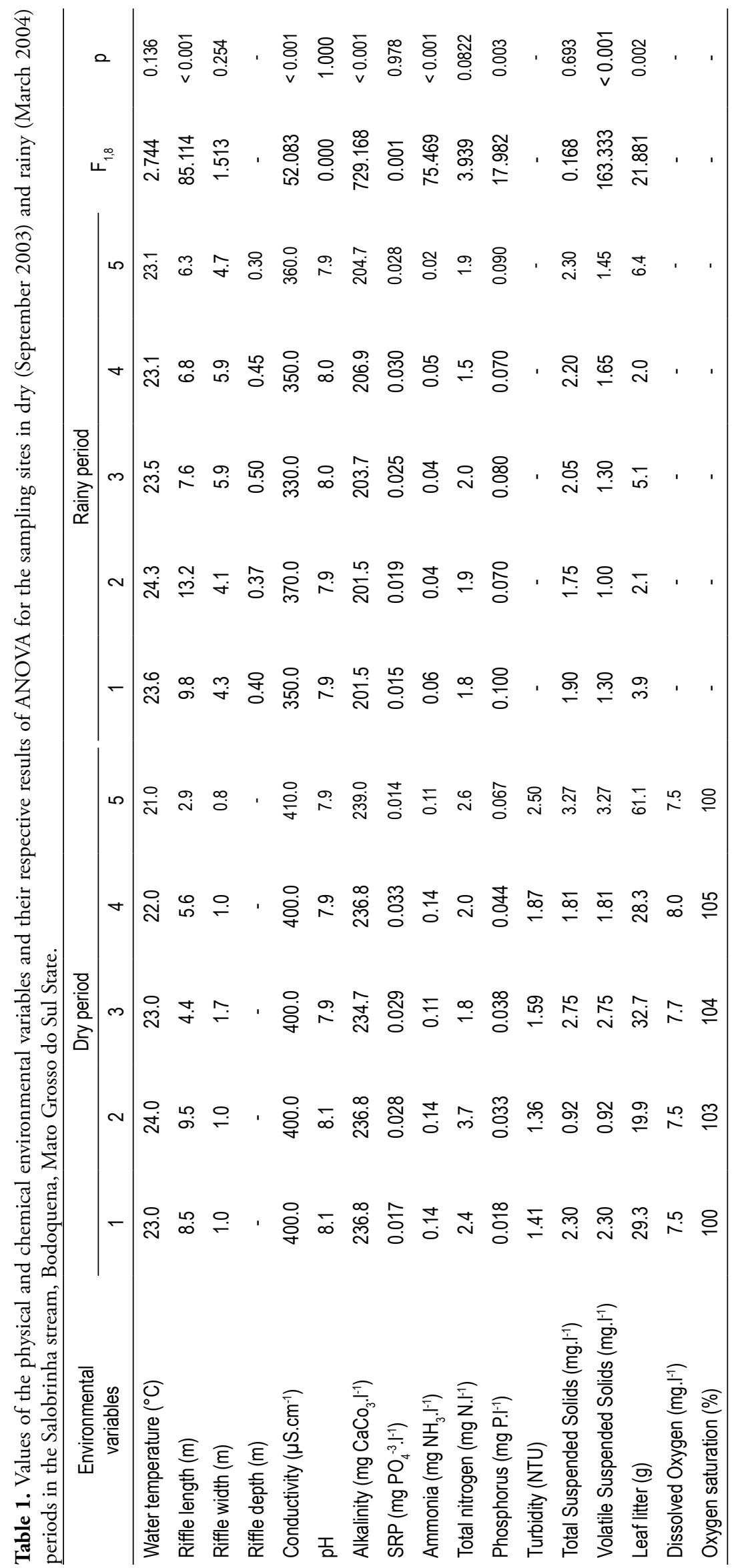


Table 2. Densities of macroinvertebrates (individuals per $\mathrm{m}^{2}$ ) collected in dry (September 2003) and rainy (March 2004) periods in the Salobrinha stream, Bodoquena, Mato Grosso do Sul State. IV = indicator value, $\mathrm{P}=\mathrm{p}$-value obtained from 5000 permutations; * indicates an indicator taxon; $\mathrm{D}=$ dry and $\mathrm{R}=$ rainy periods; + indicates taxa recorded in temporary stretches.

\begin{tabular}{|c|c|c|c|c|c|c|}
\hline Taxa & Dry & Rainy & & IV (\%) & $\mathrm{P}$ & Indicator \\
\hline Oligochaeta* & 3.9 & 0 & + & 100.0 & 0.0076 & $D$ \\
\hline Hydracarina* & 231.0 & 9.5 & + & 96.1 & 0.0076 & D \\
\hline Arachnida & 1.0 & 1.3 & & 34.3 & 0.9246 & $\mathrm{R}$ \\
\hline Curculionidae & 0.3 & 0 & & 20.0 & 1.000 & D \\
\hline Dryopidae & 2.6 & 4.6 & + & 38.2 & 0.8144 & $\mathrm{R}$ \\
\hline Dytiscidae & 6.2 & 0.7 & & 72.4 & 0.0678 & D \\
\hline Elmidae* & 1511.8 & 348.7 & + & 81.3 & 0.0076 & D \\
\hline Hydrophilidae & 2.0 & 2.0 & + & 40.0 & 0.9276 & D \\
\hline Psephenidae & 4.2 & 4.9 & + & 42.9 & 0.7396 & $\mathrm{R}$ \\
\hline Isotomidae* & 10.5 & 0 & & 80.0 & 0.0494 & D \\
\hline Entomobryidae & 7.8 & 1.3 & & 34.3 & 0.5500 & D \\
\hline Ceratopogonidae* & 28.8 & 4.6 & + & 86.3 & 0.0240 & D \\
\hline Chironomidae* & 4702.3 & 56.9 & + & 98.8 & 0.0076 & D \\
\hline Culicidae & 0.3 & 0 & & 20.0 & 1.000 & D \\
\hline Empididae & 101.3 & 4.9 & & 95.4 & 0.0076 & D \\
\hline Simuliidae* & 54.9 & 1.0 & & 98.2 & 0.0076 & D \\
\hline Stratiomyidae & 1.3 & 0.7 & & 53.3 & 0.5148 & D \\
\hline Tabanidae & 0 & 0.7 & & 20.0 & 1.000 & $R$ \\
\hline Tipulidae* & 40.8 & 2.3 & + & 94.7 & 0.0076 & D \\
\hline Baetidae & 109.5 & 25.8 & + & 80.9 & 0.2418 & D \\
\hline Caenidae & 0.3 & 1.0 & + & 45.0 & 0.5340 & $\mathrm{R}$ \\
\hline Leptohyphidae* & 35.0 & 5.2 & + & 87.0 & 0.0156 & D \\
\hline Leptophlebiidae* & 309.8 & 92.2 & + & 77.1 & 0.0162 & D \\
\hline Hebridae & 2.0 & 0.7 & & 45.0 & 0.4142 & D \\
\hline Gerridae* $^{*}$ & 4.2 & 0 & & 80.0 & 0.0442 & D \\
\hline Naucoridae & 3.9 & 2.6 & & 60.0 & 0.4540 & D \\
\hline Mesoveliidae & 0.3 & 0 & & 20.0 & 1.000 & D \\
\hline Veliidae & 1.6 & 0.3 & & 33.3 & 0.4322 & D \\
\hline Hymenoptera & 0.7 & 0 & & 40.0 & 0.4474 & D \\
\hline Pyralidae & 2.3 & 0 & & 40.0 & 0.4428 & D \\
\hline Corydalidae & 1.3 & 2.9 & + & 55.4 & 0.3916 & $\mathrm{R}$ \\
\hline Calopterygidae & 2.6 & 1.6 & & 49.2 & 0.6270 & D \\
\hline Coenagrionidae & 6.9 & 3.9 & + & 63.6 & 0.3900 & D \\
\hline Gomphidae & 16.7 & 2.9 & + & 85.0 & 0.0874 & D \\
\hline Libellulidae & 0.3 & 0.7 & + & 26.7 & 1.000 & $\mathrm{R}$ \\
\hline Orthoptera & 1.0 & 0 & & 20.0 & 1.000 & D \\
\hline Perlidae* & 91.2 & 19.6 & + & 82.3 & 0.0076 & D \\
\hline Ecnomidae & 4.6 & 2.0 & + & 56.0 & 0.3078 & D \\
\hline Glossosomatidae & 1.3 & 2.0 & + & 48.0 & 0.5142 & $\mathrm{R}$ \\
\hline Helicopsychidae & 1.6 & 11.4 & + & 70.0 & 0.1300 & $\mathrm{R}$ \\
\hline Hydropsychidae* & 151.3 & 26.1 & & 85.3 & 0.0234 & D \\
\hline Hydroptilidae* & 28.8 & 3.9 & + & 88.0 & 0.0076 & D \\
\hline Leptoceridae & 0 & 0.3 & & 20.0 & 1.000 & $\mathrm{R}$ \\
\hline Odontoceridae & 0.3 & 0 & & 20.0 & 1.000 & D \\
\hline Philopotamidae & 23.9 & 14.4 & + & 62.4 & 0.2904 & D \\
\hline Polycentropodidae & 2.9 & 1.6 & + & 51.4 & 0.5980 & D \\
\hline Planorbidae & 2.3 & 0.3 & & 35.0 & 0.4492 & D \\
\hline Thiaridae & 5.9 & 1.3 & & 65.5 & 0.1388 & D \\
\hline Hydrobiidae & 2.9 & 5.2 & & 51.2 & 0.5784 & $\mathrm{R}$ \\
\hline Planariidae & 3.9 & 4.9 & + & 44.4 & 0.7316 & $\mathrm{R}$ \\
\hline Total & 7530 & 677 & & & & \\
\hline
\end{tabular}


Table 3. Canonical Correspondence Analysis results for the three first axes. Variables and sampling sites both in dry (September 2003) and rainy (March 2004) periods in the Salobrinha stream, Bodoquena, Mato Grosso do Sul State.

\begin{tabular}{lccr}
\hline & Axis 1 & Axis 2 & Axis 3 \\
\hline Eigenvalues & 0.037 & 0.013 & 0.009 \\
Percentage & 38.588 & 13.984 & 9.575 \\
Cumulate Percentage & 38.588 & 52.572 & 62.147 \\
Canonical coefficients & & & \\
$\quad$ Condutivity & -0.890 & -0.368 & -0.108 \\
pH & -0.700 & 1.682 & -2.528 \\
Riffle length & 1.685 & -1.717 & 3.357 \\
Phosphorus & 0.562 & -0.910 & 0.638 \\
Total Nitrogen & 1.229 & -0.924 & 3.347 \\
$\quad$ Total Suspended Solids & 1.516 & -1.116 & 3.075 \\
Correlation coefficients & & & \\
$\quad$ Condutivity & -0.945 & 0.058 & 0.126 \\
pH & 0.028 & 0.744 & -0.220 \\
Riffle length & 0.603 & 0.211 & -0.193 \\
Phosphorus & -0.027 & -0.546 & -0.602 \\
Total Nitrogen & -0.428 & 0.543 & 0.212 \\
$\quad$ Total Suspended Solids & -0.197 & -0.094 & 0.238 \\
\hline
\end{tabular}

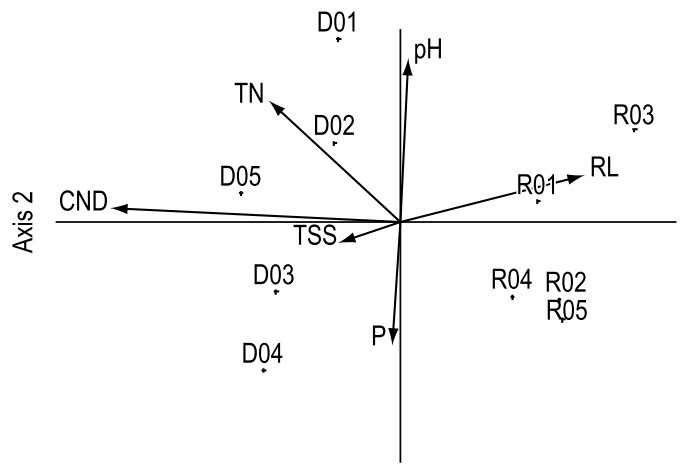

Axis 1

Figure 3. Relationships between the macroinvertebrates communities of the sampling sites and selected environmental variables as shown by Canonical Correspondence Analysis. The environmental variables are indicated as follows: Conductivity $=\mathrm{CND}$, Riffle length = RL; Phosphorus = P; Total Nitrogen $=$ TN; Total Suspended Solids $=$ TSS.

This is in accordance with previous studies done in Cerrado vegetation of central Brazil (Oliveira et al., 1997; Bispo and Oliveira, 1998; Bispo et al., 2004). In studying structure of benthic invertebrate communities in karst systems, Smith et al. (2003) and Barquín and Death (2004) found, similarly, that flow variability may lead to significant temporal variability in aquatic community abundance and structure. In fact, the rainy period of the region under study is characterized by intense periods of rainfall, with rapid increases of water current velocity and flow, with water levels rising up to $3 \mathrm{~m}$ above base-flow. These large flow and current velocity increases might lead to the removal of benthic fauna through physical disturbance of the substrate (Flecker and Feifarek, 1994).

Temporary stretches were distinguished by reduced species richness and abundance compared to sites with flow permanence, a pattern that has been reported for many other systems, including both karst and chalk streams in temperate regions (Meyer and Meyer, 2000; Stubbington et al., 2009). The relatively impoverished communities of temporary stretches reflect the inability of many taxa to maintain populations in these sites due to the fluctuation of the height of the water column. The absence of studies in karst tropical regions avoids direct comparison of our results with other studies. Therefore, understanding how this dynamic environment works will only be possible with further studies.

Food availability and shelter could have been more available in the dry season. In the present study, availability of leaf litter, potential food and substrate for the macroinvertebrates (CrisciBispo et al., 2007), was higher in the dry period. It is probable that, in the wet period, such material is transported downstream by the current. There is also the possibility that more litter is produced during the dry season through increased rates of leaf-fall from the riparian vegetation (Wantzen et al., 2008).

The high abundance of organisms during periods of low flow may also be related to the reduced availability of habitat area and the consequent increase in individuals' aggregation (Dudgeon, 1997; Diniz-Filho et al., 1998; Bispo et al., 2004). 
According to Dudgeon (1997), even if there were no reduction in fauna due to increased removal of organisms in the rainy season, the fact that the available area is decreased in the dry seasons would be sufficient to increase density.

Phosphorous concentration differed between seasons. This nutrient can affect periphyton productivity, and thus food availability, and different concentrations of ammonia could imply differing levels of toxicity (Arthur et al., 1987). However, phosphorus levels were highest and ammonia levels lowest in the wet season, when macroinvertebrates were scarcer, which is the opposite to be expected if periphyton productivity was lower and toxicity higher in the dry period.

Of the most abundant taxa found, Chironomidae is often the numerically dominant component of the benthos (Rabeni and Wang, 2001), while Elmidae is a common family in the tropics (Ramirez and Pringle, 1998; Dudgeon, 1999; Passos et al., 2003). The mayfly family Leptophlebiidae is associated with fast-flowing clean waters (Armitage et al., 1983), and Hydracarina are also common members of the benthos. The absence or scarcity of crustaceans and molluscs is of note, as such organisms are generally favoured by high alkalinity (Giller and Twomey, 1993; Wright et al., 2003). A possible reason for this low degree of representation might be the unstable hydraulic conditions exhibited by this stream (see above). Mollusca and Amphipoda can be more sensitive to removal by floods than other groups such as insects (Death, 2008), although the general poor representation of Amphipoda in tropical streams (Dobson et al., 2002) has also been, at least partially, attributed to low palatability of leaf litter in such systems (Wantzen et al., 2002). Floods have been implicated in reductions of snail density (Holomuzki and Biggs, 1999; Suren and Jowett, 2006). Previous results suggest that snails move to areas of low flow as a response to floods (Holomuzki and Biggs, 1999; Biggs, 2000). However, as revealed by the Indicator Species Analysis, snails were not abundant in the dry season.

The present study is a preliminary description of the macroinvertebrate communities of a karst stream in the center-west of Brazil. This type of environment as well as this region has been very poorly studied to date. These data should provide a basis for future studies, leading to a better understanding of the structure of these aquatic communities.

\section{Acknowledgements}

The authors are grateful to the Universidade Federal de Mato Grosso do Sul and it's Programa de Pós-Gradução em Tecnologias Ambientais for support. We would like to express our thanks to Emanuele Pomini, Luiza P. C. Lopes and Robson W. Ávila for help during field work. Alberto (from AJAC) is thanked for his hospitality during the field work. Iara A. Alves, Taciana N. F. Orikassa, Patrick I. Pina, Camila L. Silva and Mariane S. Sunada are thanked for help to sort the material. Marcia R. Spies for help with statistics analysis. The first author thanks the CNPq for financial support. The anonymous referees and Antonio Camargo are thanked for their criticisms and improvements to this manuscript.

\section{References}

ARMITAGE, PD., MOSS, D., WRIGHT, JF. and FURSE, MT., 1983. The performance of a new biological water quality score system based on macroinvertebrates over a wide range of unpolluted running-water sites. Water Research, vol. 17, p. 333-347.

ARTHUR, JW., WEST, CW., ALLEN, KN. and HEDTKE, SF., 1987. Seasonal toxicity of ammonia to five fish and nine invertebrate species. Bulletin of Environmental Contamination and Toxicology, vol. 38, p. 324-331.

BAPTISTA, DF., BUSS, DF., DROVILLÉ, LFM. and NESSIMIAN, JL., 2000. Diversity and habitat preference of aquatic insects along the longitudinal gradient of the Macaé river basin, Rio de Janeiro, Brazil. Revista Brasileira de Biololgia, vol. 61, p. 249-258.

BARQUÍN, J. and DEATH, RG., 2004. Patterns of invertebrate diversity in streams and freshwater springs in Northern Spain. Archiv für Hydrobiologie, vol. 161, p. 329-349.

BIGGS, BJF., 2000. Eutrophication of streams and rivers: dissolved nutrient-chlorophyll relationships for benthic algae. Journal of the North American Benthological Society, vol. 19, p. 17-31.

BISPO, PC. and OLIVEIRA, LG., 1998. Distribuição espacial de insetos aquáticos (Ephemeroptera, Plecoptera e Trichoptera) em córregos de Cerrado do Parque Ecológico de Goiânia, Estado de Goiás. In NESSIMIAN, JL. And CARVALHO, AC., ed. Ecologia de insetos aquáticos. Rio de Janeiro: Série Oecologia Brasiliensis, PPGE-UFRJ. vol. 5, p. 19-33.

BISPO, PC., OLIVEIRA, LG., BINI, LM. and SOUSA, KG., 2004. Ephemeroptera, Plecoptera and Trichoptera assemblages from riffles in mountain 
streams of central Brazil: environmental factors influencing the distribution and abundance of immature. Brazilian Journal of Biology, vol. 66, p. 611-622.

BISPO, PC., OLIVEIRA, LG., CRISCI, VL. and SILVA, MM., 2001. A pluviosidade como fator de alteração da entomofauna bentônica (Ephemeroptera, Plecoptera e Trichoptera) em córregos do Planalto Central do Brasil. Acta Limnologica Brasiliensia, vol. 13, p. 1-9.

BOGGIANI, PC., 1999. Porque Bonito é bonito? In: SCREMIM-DIAS, E., POTT, VJ., HORA, RC. and SOUZA, PR., ed. Nos Jardins Submersos da Bodoquena. Campo Grande: Editora da Universidade Federal de Mato Grosso do Sul. p. 10-23.

BUSS, DF., BAPTISTA, DF., NESSIMIAN, JL. and EGLER, M., 2004. Substrate specificity, environmental degradation and disturbance structuring macroinvertebrate assemblages in neotropical streams. Hydrobiologia, vol. 518, p. 179-188.

CHURCH, M., 1996. Channel morphology and typology. In PETTS, GE. and CALOW, P., ed. River Flows and Channel Forms. Oxford: Blackwell Scientific Publications. p. 185-202.

CLARKE, KR. and GORLEY, RN., 2001. PRIMER v5: user manual / tutorial. Plymouth: PRIMER-E Ltd.

CLARKE, KR. and WARWICK, RM., 2001. Change in Marine Communities. An approach to statistical analysis and interpretation. $2^{\text {nd }}$ ed. Plymouth: PRIMER- E Ltd.

COSTA, CSI., IDE, S. and SIMONKA, CE., 2006. Insetos imaturos: metamorfose e identificação. Ribeirão Preto: Holos. 249 p.

CRISCI-BISPO, VL., BISPO, PC. and FROEHLICH, CG., 2007. Ephemeroptera, Plecoptera and Trichoptera assemblages in litter in a mountain stream of the Atlantic Rainforest from Southeastern Brazil. Revista Brasileira de Zoologia, vol. 24, p. 545-551.

CUMMINS, KW. and KLUG, MJ., 1979. Feeding ecology of stream invertebrates. Annual Review of Ecology and Systematics, vol. 10, p. 147-172.

DAMASCENO Jr., GA., NAKAJIMA, JN. and REZENDE, UM., 2000. Levantamento florístico das cabeceiras dos rios Negro, Aquidauana, Taquari, Miranda no Pantanal, Mato Grosso do Sul, Brasil. In WILLINK, PW., CHERNOFF, B., ALONSO, L., MONTAMBAULT, JR. and LOURIVAL, R., ed. RAP Bulletin of Biological Assesment, 18: uma avaliação biológica dos ecossistemas aquáticos do Pantanal, Mato Grosso do Sul, Brasil. Washington: Conservation International. p. 152-162.
DEATH, RG., 2008. The effect of floods on aquatic invertebrate communities. In LANCASTER, J., BRIERS, R. and MACADAM, C., ed. Aquatic insects: challenges to populations. p. 103-121. CABI: Proceedings of the Royal Entomological Society's $24^{\text {th }}$ Symposium.

DINIZ-FILHO, JAF., OLIVEIRA, LG. and SILVA, MM., 1998. Explaining the beta diversity of aquatic insects in "cerrado" streams from Central Brazil using multiple Mantel Test. Revista Brasileira de Biologia, vol. 58, p. 223-231.

DOBSON, M., MAGANA, AJM. and NDEGWA, FK., 2002. Detritivores in Kenyan highland streams: more evidence for paucity of shredders in the tropics? Freshwater Biology, vol. 47, p. 909-919.

DUDGEON, D., 1997. Life histories, secondary production, and microdistribution of hydropsychid caddisflies (Trichoptera) in a tropical forest stream. Jounal of Zoology, vol. 243, p. 191-210.

DUdGEON, D., 1999. Tropical Asian Streams Zoobenthos, ecology and conservation. Hong Kong: Hong Kong University Press. 830 p.

DUFRÊNE, M. and LEGENDRE, P., 1997. Species assemblages and indicator species: the need for a flexible asymmetrical approach. Ecological Monographs, vol. 67, p. 345-366.

FAVERO, S. and CONTE, CO., 2003. Entomofauna aquática associada à macrófitas em uma baia do pantanal do rio Negro, Mato Grosso do Sul. Ensaios e Ciência, vol. 7, p. 481-487.

FERNÁNDEZ, HR. and DOMÍNGUEZ, E., 2001. Guía para la determinación de artrópodos sudamericanos. Argentina: Editorial Universitaria de Tucumán. $282 \mathrm{p}$.

FLECKER, AS. and FEIFAREK, B., 1994. Disturbance and temporal variability of invertebrate assemblages in two Andean streams. Freshwater Biology, vol. 31, p. 131-142.

FORD, DC. and WILLIAMS, P., 2007. Karst Hydrogeology and Geomorphology. England: John Wiley \& Sons LTD. 576 p.

FROEHLICH, CG., 1984. Brazilian Plecoptera 4. Nymphs of perlid genera from southeastern Brazil. Annales de Limnologie, vol. 20, p. 43-48.

FROEHLICH, CG., 2007. Three new species of Anacroneuria (Plecoptera: Perlidae) from the State of Mato Grosso do Sul, Brazil. Zootaxa, vol. 1461, p. $15-24$.

GILLER, PS. and TWOMEY, H., 1993. Benthic macroinvertebrate community organization in two contrasting rivers: between-site differences and seasonal patterns. Biology and Environment, vol. 93, p. $115-123$. 
HOLOMUZKI, JR. and BIGGS, BJF., 1999. Distributional responses to flow disturbance by a stream-dwelling snail. Oikos, vol. 87, p. 36-47.

JENNINGS, JN., 1985. Karst geomorphology. Oxford: Blackwell. 293 p.

KIKUCHI, RM. and UIEDA, VS., 1998. Composição da comunidade de invertebrados de um ambiente lótico tropical e sua variaçáo espacial e temporal. In NESSIMIAN, JL. and CARVALHO, AL., ed. Ecologia de insetos aquáticos. Rio de Janeiro: PPGEUFRJ. p. 157-173. Série Oecologia Brasiliensis, vol. 5.

KOHLER, SL., 1992. Competition and the structure of a benthic stream community. Ecological Monographs, vol. 62, p. 165-188.

KOVACH COMPUTING SERVICE., 2006. MVSP - Multi-Variate Statistical Package. Version 3.13 for Windows. Anglesey.

MCCUNE, B. and MEFFORD, MJ., 1999. PC-ORD. Multivariate analysis of ecological data. Version 4.1. Gleneden Beach, Oregon, USA: MjM Software Design.

MELO, AS. and FROEHLICH, CG., 2001. Macroinvertebrates in neotropical streams: richness patterns along a catchment and assemblage structure between two seasons. Journal of the North American Benthological Society, vol. 20, p. 1-16.

MERRITT, RW. and CUMMINS, KW., 1996. An introduction to the aquatic insects of North America. Dubuque: Hunt Publishing. 862 p.

MEYER, AM. and MEYER, EI., 2000. Discharge regime and the effect of drying on macroinvertebrate communities in a temporary karst stream in East Westphalia (Germany). Aquatic Sciences, vol. 62, p. 216-231.

MEYER, AM., MEYER, EI. and MEYER, C., 2003. Lotic communities of two small temporary karstic stream systems (East Westphalia, Germany) along a longitudinal gradient of hydrological intermittency. Limnologica, vol. 33, p. 271-279.

NIESER, N. and MELO, AL., 1997. Os heterópteros aquáticos de Minas Gerais. Belo Horizonte: Editora UFMG. 177 p.

OLIVEIRA, LG., BISPO, PC. and SÁ, NC., 1997. Ecologia de assembléias de insetos bentônicos (Ephemeroptera, Plecoptera e Trichoptera), em córregos do Parque Ecológico de Goiânia, Goiás, Brasil. Revista Brasileira de Zoologia, vol. 14, p. 867-876.

PASSOS, MIS., NESSIMIAN, JL. and DORVILLÉ, LFM., 2003. Life strategies in an elmid (Insecta: Coleoptera: Elmidae) community from a first order stream in the Atlantic Forest, southeastern Brazil. Acta Limnologica Brasiliensia, vol. 15, p. 29-36.
RABENI, CF. and WANG, N., 2001. Bioassessment of streams using macroinvertebrates: are the Chironomidae necessary? Environmental Monitoring and Assessment, vol. 71, p. 177-185.

RAMIREZ, A. and PRINGLE, CM., 1998. Structure and production of a benthic insect assemblage in a neotropical stream. Journal of the North American Benthological Society, vol. 17, p. 443-463.

SANDIN, L. and HERING, D., 2004. Comparing macroinvertebrate indices to detect organic pollution across Europe: a contribution to the EC Water Framework Directive intercalibration. Hydrobiologia, vol. 516, p. 55-68.

SIEGFRIED, CA. and KNIGHT, AW., 1977. The effects of a washout in a sierra foothill stream. American Midland Naturalist, vol. 98, p. 200-207.

SMITH, H., WOOD, PJ. and GUNN, J., 2003. The influence of habitat structure and flow permanence on invertebrate communities in karst spring systems. Hydrobiologia, vol. 510, p. 53-66.

STATZNER, RB., GORE, JA. and RESH, VH., 1988. Hydraulic stream ecology: observed patterns and potential applications. Journal of the North American Benthological Society, vol. 7, p. 307-360.

STUBBINGTON, R., GREENWOOD, AM., WOOD, PJ., ARMITAGE, PD., GUNN, J. and ROBERTSON, AL., 2009. The response of perennial and temporary headwater stream invertebrate communities to hydrological extremes. Hydrobiologia, vol. 630, p. 299-312.

SUREN, AM. and JOWETT, IG., 2006. Effects of floods versus low flows on invertebrates in a New Zealand gravel-bed river. Freshwater Biology, vol. 51, p. 2207-2227.

TANAKA, MO., RIBAS, ACA. and SOUZA, ALT., 2006. Macroinvertebrate succession during leaf litter breakdown in a perennial karstic river in Western Brazil. Hydrobiologia, vol. 568, p. 493-498.

TOWNSEND, CR., HILDREW, AG. and SCHOFIELD, K., 1987. Persistence of stream communities in relation to environmental variability. Journal of Animal Ecology, vol. 56, p. 597-613.

WALLACE, JB. and WEBSTER, JR., 1996. The role of macroinvertebrates in stream ecosystem function. Annual Review of Entomology, vol. 41, p. 115-139.

WANTZEN, KM., WAGNER, R., SUETFELD, R. and JUNK, J., 2002. How do plant-herbivore interactions of trees influence coarse detritus processing by shredders in aquatic ecosystems of different latitudes? Verhandlungen des Internationalen Verein Limnologie, vol. 28, p. 815-821.

WANTZEN, KM., YULE, CM., MATHOOKO, JM. and PRINGLE, CM., 2008. Organic matter 
processing in tropical streams. In DUDGEON, D., ed. Tropical stream ecology. London: Elsevier. p. 43-64.

WOOD, PJ., HANNAH, DM., AGNEW, MD. and PETTS, GE., 2001. Scales of hydroecological variability within a groundwater-dominated stream. Regulated Rivers: Research \& Management, vol. 17, p. 347-367.

WRIGHT, JF., 1995. Development and use of a system for predicting macroinvertebrates in flowing waters. Australian Journal of Ecology, vol. 20, p. 181-197.
WRIGHT, JF., CLARKE, RT., GUNN, RJM., WINDER, JM., KNEEBONE, NT. and DAVYBOWKER, J., 2003. Response of the flora and macroinvertebrate fauna of a chalk stream site to changes in management. Freshwater Biology, vol. 48, p. 894-911.

Received: 13 June 2010 Accepted: 01 February 2011 